\title{
The Phenomenon of Space and Time Deixis in Patients with Broca's Aphasia
}

\author{
Lilis Hartini ${ }^{1 *}$ Dadang Sudana ${ }^{1}$ Wawan Gunawan ${ }^{1}$ Nyi R. Nuraini Siti Fhatonah ${ }^{2}$ \\ ${ }^{1}$ Postgraduate School of Universitas Pendidikan Indonesia, Bandung, Indonesia \\ ${ }^{2}$ Technical Information, Politeknik Pos Indonesia, Bandung, Indonesia \\ *Corresponding author. Email: lilishartini90@gmail.com.
}

\begin{abstract}
Broca's aphasia is a left brain disorder that affects the ability to produce language. Patients with Broca's aphasia have difficulty expressing ideas so that they speak a little, stutter, and often use gestures. The pragmatic theory in this study aims to reveal the meaning of deixis in speech that is informed by a subject with expressive aphasia. Patients often deal with communication by using spatial deixis and time deixis. The study was conducted using a qualitative descriptive method with a case study approach to a stroke patient that had an impact on lesions in the Broca's area. For more than 18 years, the patient has experienced expressive aphasia with the condition getting worse in language. The object of study is in the form of speech and gestures exhibited by informants when conveying messages to listeners. The technique of data collection was through observations and the results were recorded and described in the form of field notes. Data analysis used deixis theory as a framework in revealing the informants' deictic speeches relating to space and time as their communication strategy. The results of the study proved that there are findings in the form of difficulties of the informants in calling out words in their mental lexicon related to the designation of place and time. This makes informants tactics to combine speech with gesture.
\end{abstract}

Keywords: spacial deixis, time deixis, Broca's aphasia

\section{INTRODUCTION}

There have been many studies of Broca's aphasia conducted by experts in the fields of neurology, pathology, psychology, and clinical linguistics. However, to the best of the researcher's knowledge, not many clinical linguistic studies have investigated Broca's aphasia based on the phenomenon of deixis. Therefore, this study was conducted based on the many communication strategies used by people with aphasia using space deixis and time deixis.

The use of deixis is commonly found in people with aphasia with conditions that have decreased memory. This language disorder causes sufferers to find it difficult to express everything they want. Finally, the patient performs a communication tactic using deixis and gestures. The case that researchers are observing is one of the cases of language disorders in patients with Broca's aphasia. The patient is a man who has experienced Broca's aphasia for 18 years. Broca's aphasia was caused by a hemorrhagic stroke. Hemorrhagic stroke occurs due to the rupture of a blood vessel in the brain. The impact that occurs is sufferers have difficulty in communicating. Communication disorders experienced by sufferers are speaking ineloquently, stammering, speaking with many stops, speaking efficiently with the characteristic of using deixis and gestures in every utterance. When speaking, informants always combine deixis with gestures.

Several studies have concluded that one of the hallmarks of communication strategies in language disorders is the use of gestures. In this regard,Sekine, $\mathrm{K}$ $\&$ Rose (2013) said that in general, gestures are an important component for people with aphasia in transferring roles. The movement shown by the patient pathologically can be used as a reference to determine the pattern of movement production associated with certain types of aphasia. For Kong, A. P. H., Law, S. P., 
Wat, W. K. C., \& Lai (2015) people with aphasia use gestures, iconic, metaphorical, deictic gestures, and symbols to enhance language messages and provide additional information on language messages. In contrast to the results of a study by Fontanari (1987) which concluded that the instability of patients with Broca's aphasia in understanding and using time and place deixis did not reveal this anomaly in unnatural conditions. These findings suggest that metalanguage is impaired with specifically affected temporo-spatial elements, and it is possible that there is a reduction in the loss of discourse linkage with verbal and nonverbal contexts when mediation is made by pragmatic linkages in frontal lesions. Meanwhile, Varley (1993) examined the use of forms of deixis in conversational speech of fluent and non-fluent aphasic subjects and subjects with right hemisphere damage.

Tools in the form of electronic boards, pictures and symbols have been provided for people with aphasia who have communication disorders. However, not all of the patient's families have these tools because these electronic boards are usually only used by therapists in hospitals. Some researchers also use gestures as a therapy material for people with Broca's aphasia, among them by Daumüller, M., \& Goldenberg (2010) researching therapy to increase gestural expression in people with aphasia. De Ruiter, J. P., \& de Beer (2013) said that experts who researched aphasia began to pay attention to the gestures of people with aphasia. Therefore, a number of models of gestures and speech used by sufferers when speaking are made to guide speech participants to understand speech when communication occurs. According to Nispen, K. (2017) in general, people with aphasia produce a lot of movements to convey messages in communication. Gestures for people with aphasia can be used as tools to replace lost information in conversation, as well as deixis and symbols. It is hoped that the study of gestures can improve communication skills for people with Broca's aphasia.

Existing studies have clearly established the use of deixis and gestures, so that they can be used as references in further research and of course to determine the characteristics of aphasia sufferers in communication strategies. However, after reading the results of the study of linguists, they have not discussed in detail the role of deixis to complete the communication built by people with Broca's aphasia. They do not explore more deeply how the deixis performed by the sufferer. Does the gesture deixis match their model or not? Except for Varley (1993) who revealed a more in-depth study of deixis on people with aphasia. According to Varley in [8], significantly deixis is used by subjects affected by fluent and non-fluent aphasia. For him, the use of deixis has no causal relationship with performance on lexical tests. Furthermore, Cummings emphasized that clinical studies of deixis regarding the role of context should be carried out in the area of pragmatic disorders.

This has become the interest of researchers to examine the problem of deixis in cases of patients with Broca's aphasia. Generally, linguists also research persona deixis to see the characteristics of people who have language disorders when communicating. For researchers, deixis which covers space and time is then used as a reference in studying communication disorders in patients with Broca's aphasia in terms of gesture deixis. To achieve this goal, the researcher uses the deixis theory from several experts. According to Levinson, deixis can be related to the context of an utterance when it is used in communication.

\section{Deixis}

Talking about deixis cannot be separated from the context of communication between speakers and listeners. The communication built by the two is always associated with the indication of the context of the situation so that a meaning arises from the point of view of the speaker and listener. Each explanation of the meaning of certain utterances essentially depends on the deixis reference with certain characteristics in a context. Gesture is body language as a way of non-verbal communication through body movements, the purpose of which is to help understand an utterance. Gesture or expression deixis is one of the out-of-speech designations in addition to symbolic deixis.

Lyons (1977) says that the word deixis comes from the Greek deiktikos, which means 'to point' or 'to show'. This claim has been used as a technical term in linguistics. Therefore, every linguist interprets deixis with 'show words' to determine the 'show' context of speech through language. Deixis is also called lexically and grammatically contextual information which refers to certain things, either objects, places, or times, for example he, here, now. The three expressions give orders to designate certain contexts so that the meaning of the utterance can be understood firmly. Tense is also a type of deixis. For example then can only be referenced from the situation. Besides Lyon (1977), the deixis theory has been proposed by Jespersen (1943), Jakobson (1971) in Fludernik (2009), Fillmore (1971), 
Silverstein (1972), Brecht (1974), and Ebeling (1978) in . Fillmore's view of deixis is that the speaker is at the center of deixis. So if we say this it means close to the speaker and that it means far from the speaker. Fillmore also distinguishes between gesture deixis and symbolic. Pointing or showing things with body movements are called gestures and those that do not use body movements are called symbols.[11]

In practice, Levinson divides deixis into five categories, namely person deixis, place deixis, time deixis, deixis, discourse, and social deixis. ([12], Lyon, 1977, Fillmore, 1971) says that deixis is egocentric, i.e the speaker is at the zero point, just as person deixis refers to the speaker as the center of deixis; place deixis refers to the speaker's place when speaking; time deixis refers to the time the speaker is speaking; discourse deixis refers to the discourse put forward by the speaker when speaking; and social deixis refers to the social status of the speaker of the person referred to when speaking. Deixis depends on the interpretation of the speaker. Deixis is one part of pragmatics which discusses the expression or context in a sentence. For Purwo (1984:1) a word is called deixis if the word in question changes its meaning depending on who is the speaker and depends on the time and place where the word is spoken, for example: you, here, tomorrow. According to him, only referential meanings can enter into deixis. It is further emphasized that this referential meaning is also a meaning that can move according to who is expressing the utterance containing the element in question. The displacement of the lexeme deixis is caused by the speaker's utterance of the lexeme, not what is meant by the speaker. It is clear here that the element whose referent can be identified only by paying attention to the speaker's utterance and the time and place where the utterance is uttered by the speaker.

Fludernik (2009) in his article says that some linguists such as Jepersen (1943) and Jakobson (1971) use the term shifters for deixis. This term is used to show a broader sense, which refers to the meaning based on the context. Shifter is a sentence element that alternates between deixis and non-deixis forms. For example: Aerobic exercise is easy for teenagers, but not easy for seniors. Levinson (1983) says that deixis can reflect the relationship between language and context more clearly. With regard to gestures, Levinson claims that gestures are one way of expressing deixis expressions. Cummings (1999) states that some linguistic expressions provide better examples of the relationship between language and context than just deixis terms. For Cummings clinical studies based on deixis regarding the role of context should be carried out in the area of pragmatic disorders.

\section{Aphasia Broca's}

Broca's aphasia is a language disorder caused by damage to the part of the brain that regulates language function. In general, it is located predominantly in the left cerebral hemisphere of the brain. [14]; [15]; [16] According to ([17]; [18]; [19]) this language disorder is caused by brain trauma, brain tumors, stroke, or other lesions in the brain. Brain is not fully known. Stroke often has an impact on the occurrence of Broca's aphasia. Broca's area is responsible for motor speech execution. Lesions in this area will cause difficulty in articulation but the patient can understand language and writing (Guyton and Hall, 2006).

Broca's aphasia is also known as motor aphasia, expressive aphasia, non-fluent aphasia. According to Guyton \& Hall, the characteristics of communication disorders in patients with Broca's aphasia are limited speech output, using short sentences and simple speech forms, often accompanied by poor articulation and rhythm of speech. Broca's aphasia is a syndrome of nonfluent aphasia characterized by difficult verbal output, dysarthria, dysprosody and grammar. Patients with Broca's aphasia still have a complete understanding but often have difficulty mastering spoken and written language in special grammatical relationships.

\section{METHOD}

This research is a case study using John W. Creswell's qualitative approach. The reason for using this method is to explore and understand the meaning that comes from social or humanitarian problems. [20] A qualitative approach is used because the data analyzed are in the form of speeches of people with Broca's aphasia. The case study in this study was conducted to reach research conclusions about the use of deixis from the patient or the sufferer. The aim is to describe the spatial deixis and time deixis used by him when he is making communication strategies. Then the researcher interprets the meaning of the patient regarding the deixis of space and time. Next, it is continued by explaining the context in the data.

The procedure used in completing the research data is the source of research data. The informant as the research subject is a sufferer of Broca's aphasia who 
comes from West Java, so Sundanese is his first language. Therefore, the data collected were generally Sundanese speech. However, there were some data which were code mixing between Sundanese and Indonesian. As a research instrument, the researchers made direct observations of the informant as a research subject. Furthermore, the researcher collected data in the form of the informant's words and actions when communicating. In conclusion, the data are needed to answer the aphasia problems suffered by the informant when communicating in the form of speech or movements that contain deixis. The utterances or body movements made by the informant were then recorded and written down in full in the form of field notes. The collected data were selected for the purposes of this research. The last procedure, after there are findings in the data, the data were analyzed and then concluded.

In analyzing the data, the researcher will dissect the words, phrases, or sentences, as well as the body movements presented by the informant. Based on the data obtained, one by one is described in the form of data analysis strengthened by expert theory. Then the data are explored to get findings about deixis from the data. The findings will be interpreted by looking at the characteristics of the informant as a sufferer of Broca's aphasia or his environment. Because the respondent's speech cannot be separated from what he thinks, characteristics of people with Broca's aphasia cannot be separated from the meaning process. Therefore, his mental condition and thought are also important factors why the utterance can come out of his mouth. In addition, environmental conditions, both family and neighbors, are supporting factors to determine the characteristics of informants. In the end, a discussion of the results of data analysis is carried out.

In practice, experts divide deixis into five categories, namely personal deixis, spatial deixis, time deixis, deixis, discourse, and social deixis. (Levinson, 1983, Lyon, 1977, Fillmore, 1971) say that deixis is egocentric, i.e the speaker is at the zero point, just as personal deixis refers to the speaker as the center of deixis; spatial deixis refers to the speaker's place when speaking; time deixis refers to the time the speaker is speaking; discourse deixis refers to the discourse put forward by the speaker when speaking; and social deixis refers to the social status of the speaker of the person referred to when speaking. Deixis depends on the interpretation of the speaker. Characteristics of informants in communicating a lot of circumventing their speech by using spatial deixis and time deixis. This phenomenon is the subject of research analysis.

\section{FINDINGS AND DISCUSSION}

During the observation of the informants, the researcher obtained a lot of spatial or place deixis data along with time deixis. There were some conflicting data in interpreting the respondent's intention in pointing out something, when the researcher communicated with the informant. Because of this asynchronism, the words uttered by the movements exhibited by the informants are interesting to analyze their meanings. The dots (...) written in the speech data are markers of silence because the informant found it difficult to call out the words in his mind. Generally, the silence was replaced by gestures.

The analyzed data are grouped into two categories, namely

\section{Spatial Deixis}

Spatial deixis is indicated by lexical units related to direction and space (place, location), such as this, that, here, there, and there. The following data are taken from field notes resulting from data processing, which show place deixis.

\section{Data:}

1. I: Ade...itu...tot...tot.../ itu...itu...

2. I: itu ... itu aya cucian ('that's... the laundry')

Is: Iya ini baju sudah kotor, mau dicuci.

I : tah ieu... ('Well, this one...')

3. I: Ayeuna kudu .... ka ditu.... ka dieu? ("now have to... go there... come here?)

Analysis: data (1) was taken when the informant asked his child to buy pure milk. Incidentally, the characteristic of milk sellers when selling milk used sounds to attract the attention of buyers. The informant said 'Ade...that's...tot...tot..." while pointing at the sound using his index finger. Then because there was no response from the interlocutor, the informant moved towards the door and pointed at the door while repeating his speech by saying 'that...that' with a face full of regret because it was difficult to express the content of the message he wanted to convey. In data (1), the informant performed a dynamic movement towards where the speech partner is, then moved towards the door. When moving towards the door, the informant actually intended to show the interlocutor to get out of 
the door and chase the milkman. This was indicated by the hand constantly pointing outwards. In deixis, the word is intended as a direction word that is far from the speaker. The distance between the informant pointing at the door and the distance between the informant pointing to a place outside the door is not the same. The first goal when making speech is a direction that is farther from the door. However, because there was no response from the interlocutor, the informant pointed to the door. The speech that pointed to the door was a location not far from the informant. While the milkman is the designated location outside the door, which was further from the door and may be further away when the sound of the sign from the milkman was getting less and less audible. Therefore, the place deixis spoken by the informants is different. Although, the words used are the same, namely the word as a place marker.

Data (2) "itu...itu aya cucian"(" that's... that's the laundry') is a combination of speech and gesture by pointing at the clothes that his wife was holding. Then his wife responded by looking at the clothes and agreeing that the clothes would be washed. However, the informant shook his head and went to his wife and took the key in his shirt pocket. The meaning of the informant's speech by saying that and pointing at the clothes is not the same as the inference of the speech partner. The interlocutor assumed that the informant did not want his clothes to be washed, so the interlocutor confirmed that it was true that his clothes would be washed because they were already dirty. After the informant had gone to the speech partner and taken the key from a pocket of his dirty shirt, then the speech partner understood the meaning of the informant's speech. Same as in data (1), in deixis the word refers to a location far from where the informant is. In data (2), the word the informant meant was not referring to the clothes his wife was holding, but to an object inside the clothes, namely the key. It means that the distance between the informant and the clothes and the distance between the informant and the key is the same because the key is still in the shirt. However, when the informant went to his wife and took the key from his shirt pocket the distance became close. It was because the informant said tah ieu ('here this is'). Spatial deixis ieu in Indonesian means this. This word refers to something close to the speaker. So the distance between the informant and the key is closer and sticks to the informant's hand because the informant held the key, then showed it to the interlocutor, and told her that what he informed was a key in his dirty shirt pocket. In deixis the word ieu 'this' is a word indicating a place that is close to the speaker.

Data (3) was taken when the informant asked about a direction, namely pointing outside the house by moving the index finger forward and towards the right side alternately. The sentence "ayeuna kudu .... ka ditu... ka dieu?" ('Now I have to... go there... here?') often used by the informant when communicating with the interlocutor so that the speech partner understands the meaning of the informant's speech, namely asking whether today's prayer is at the mosque or at the mushala. The word ka ditu 'there' refers to a mosque which is far from the informant. Meanwhile, the word ka dieu 'here' refers to a distance not so far from the informant. Actually, in deixis, the reference word here is close to the informant, but in the context of the speech, the prayer room is far away from the informant. However, in fact, the distance between the mosque and the prayer room is different. The prayer room is closer to the informant than the mosque, so the informant points to the prayer room with the word ka dieu. The context of the sentences spoken by the informants contained adverbs of time and adverbs of place. The time deixis used by the informant is the word ayeuna 'now', which shows the current time or the day the informant is experiencing.

The findings obtained in data (1) and (2) are the same, namely the informant said the word "it" and went to the speech partner to clarify his speech. With the hope that the speech partner could understand his speech. Gestures exhibited by the informant make the speech uttered by the informant understandable to the speech partner. The word "itu" is intended to designate a place far from the informant. The place reference in the data does not depend on the time of making the speech because the distance indicated is determined by the distance or proximity of the speaker's location. This can be seen from the sentences uttered by the informants. The sentences contain expressive deixis because in addition to being spoken, they are also given expressions in the form of gestures by pointing to two locations alternately, namely (1) the door and the milkman, and (2) pointing to the shirt and shirt pocket. (Lyons, 1977; Fillmore (1971; Purwo, 1984; Cummings, 1999; Djajasudarma, 2016) mention that spatial deixis involves demonstrative pronouns and the concepts of distance and place are related to spatial deixis. The same demonstrative pronoun was used by the informant to achieve spatial deixis. Spatial deixis is referred based on the point of view of a far distance or close to the speaker. Fillmore also said that the word 
that (itu) spoken by the informant shows spatial deixis. For Fillmore, the informant and the speech partner must have the same orientation in dealing with an information or message.

In Sundanese we know spatial deixis markers, namely ieu, eta, and itu. Ieu to point to a place that is close to the speaker and the word eta refers to a place that is a bit far from the speaker. The distance is between ieu and itu. Itu is to point at a place far from the speaker. In Indonesian, only this and that deixis are known. On the contrary, locative deixis such as here, there, and there, in Sundanese only has two forms, namely the word dieu for a location close to the speaker and ditu for a location far from the speaker. This statement relates to the findings of data (3) that the locative deixis used by the informant begins with the preposition ka 'ke' (meaning to/towards). According to (Purwo, 1984:51) the preposition ke describes things that move; as the intended introduction; or asking the destination. In data (3) the deixis used by the informants is intended to question of the place of destination, namely to go to the prayer room or to the mosque. In his theory, Purwo says that new nouns can become locative if they are combined with prepositions of space. Spatial lexemes can be adjectives, adverbs, or verbs. A lexeme that is not a deixis becomes a deixis when it is combined with a personal lexeme. The finding is that the informant in his speech did not include nouns but the meaning of the sentence is deixis. This is because the informants find it difficult to find the core words in his short term memory so that the words he needs just disappears. The nouns referred to in the speech refer to the prayer room and mosque. Regarding the deixis of space and time in the data (3), Fillmore, 1971; Traugott, 1975; and Lyons, 1977 agree that every preposition that is locative is also temporal. This is evident from the utterances spoken by the informant. Fillmore said that there are two meanings of motion associated with time, namely we are moving through time. Here time is assumed to be stationary. Furthermore, time is moving towards us and passing us.

In discussing the results of the analysis, the researchers expressed the opinions of experts which were the results of references from the findings obtained. According to Cummings (2009), a very difficult task in interpreting the intentions of people with aphasia is caused by utterances that not only have a declarative form but also function to convey requests. In other word, it does not only provide information to the speech partner. This is explained by Greschwind (1981) that sufferers of Broca's aphasia have difficulty in speaking a word so that sufferers show verbal expressions that are not fluent. This is because there is damage in the Broca area. Paralysis of speech muscles due to motor nerve damage, resulting in patients experiencing communication disorders. For Levinson to clarify the purpose of communication from people with aphasia, is by adding gestures. Therefore, gesture is an expression of deixis. Levinson claims that language disabilities can be investigated using elements of deixis. The phenomenon of deixis can reflect the relationship between language and context in the structure of the language itself. This is in line with Yule (1996:26) that the interpretation of deixis speech depends on the context, the speaker's intention, and the expressions indicate a distance relationship.

\section{Time Deixis}

Time deixis designation, can use the words now, yesterday, tomorrow, the day after tomorrow, etc. In general, informants say today or tomorrow not to indicate the time but to ask about the time of worship, for example Friday prayer, prayer, prayer room, or mosque.

\section{Data:}

4. Ayeuna mah sangsara. ('now (I'm) suffering')

5. Ayeuna jam sabaraha? ('What time is it now?')

6. Hari naon ieu? ('What day is it today?')

7. Ayeuna...geus bulan naon? ('now...what month is it?')

8. Kumaha ayeuna...tahun naon ieu? ('how is it now... what year is it?')

Data (4) was taken when the informant was feeling frustrated with his situation so that the sentence ayeuna mah sangsara ('now suffering') was uttered. In deixis analysis, the word now refers to the time that the speaker and hearer are currently experiencing, namely throughout the day. However, the word now spoken by the informant does not only refer to the present but also refers to the time when the informant has difficulty expressing ideas when communicating, that is, since the informant felt an obstacle in retrieving words from his mental lexicon, due to the stroke he suffered. Data (5), (6), (7), and (8) have the same speech intent, using different question words and different time to get the data. The informants in the four data actually wanted to know when it was Friday. Is today Friday? However, the words that came out were (5) ayeuna jam sabaraha?; (6) Hari naon ieu?; (7) Ayeuna...geus bulan naon?; and 
(8) Kumaha ayeuna...tahun naon ieu? In deixis analysis, the word ayeuna 'now' refers to the time the informant said the word. However, the utterances of the informants who asked the hour, day, month, and year did not refer to the actual hour, day, month, and year. However, he pointed to Friday. Friday's appointment depends on when the informant's question is asked. If he asks on Saturday, it means pointing to the next week. If Thursday, it means pointing to tomorrow. If he asks on Friday morning, it means pointing a few hours ahead.

The findings obtained in data (4) are informants carried out communication strategies to express their feelings by using the word now (ayeuna). Djajasudarma (2016) states that time deixis is related to the temporal structure. According to him, time lexemes are deixis if the speaker becomes the benchmark, as in data (4). The 'now' word according to Yule (1996) is in the proximal form which shows the time the informant speaks and the time the voice of the informant is heard by the speech partner.

All expressions of time deixis depend on their understanding of the relevant knowledge of speech time. We can treat time events as objects moving towards us or moving away from us. According to Purwo (1984) the time lexeme is deictic if the speaker is the benchmark. In the data (5) to (8) the benchmark time appointed by the informant is different. However, the meaning of the speech is the same, namely asking for Friday to carry out Friday worship. The speech partner understands the meaning of the informant's speech because the informant often asks about the same thing, so it is clear here that the informant's knowledge of the time deixis appointed by the informant is relevant to the informant's communication strategy. As a person with aphasia, the informant has problems in his short term memory area so that words that should be uttered cannot be withdrawn and become lost so that the informant also forgets. If it is observed from the four data, only the speech in data (6) has the right meaning. So actually utterances (5), (7), and (8) refer to data (6). However, because of the language disorder he suffered, the informant carried out a communication strategy using time deixis with different appointments. The condition of the informant who is expressing his heart is in accordance with Yule's theory (1996), namely that deixis based on the informant's point of view can be applied mentally and physically. Psychologically, the informant marked the time only to point at an important time for him, namely to carry out worship on every Friday. The informant has tried to ask questions with the assumption that his speech is correct and can be understood by his interlocutor. The finding is that the informant's communication strategy is successful when the informant repeats the same message even though the designated time deixis has different meanings. This success is also supported by the knowledge of the speech partner and the same linguistic nature between the informant and his partner so that the time deixis informed by the informant can be interpreted by the speech partner in accordance with the expectations of the informant.

In discussing the results of the analysis, the researcher pays attention to the psychological aspects of informants who have experienced forgetfulness. Psychologically, informants have obstacles in uttering words from their mental lexicon so that their communication strategies often fail. The failure of the informant to communicate makes the informant feel depressed because the message he wants to convey cannot be understood by the speech partner. According to Yule, the psychological basis of time deixis is the same as that of place deixis, namely objects that move towards us and move away from us. Time deixis can be used not only to convey the time interval of the occurrence, but also the reality or facts of the incident.

\section{CONCLUSION}

One of the most important body parts for humans is the brain. Therefore, the brain has the function of regulating and coordinating human activities. The brain is also one of the organs of the body that has factors that affect human memory. The brain is very closely related to memory. The language disorder suffered by the informant was related to a lesion in the left side of the brain so that the informant experienced Broca's aphasia and had an impact on barriers to communication. Broca's aphasia was also hindered by a disturbance in his short term memory. This results in informants often forgetting the words that will be used in making messages to listeners.

Speech is a reflection of the work of the human mind. The use of speech is to transfer our mental discourse into verbal discourse, by transferring a series of thoughts into the form of words. In patients with Broca's aphasia, the transfer of mental discourse to verbal discourse is hindered so that sufferers find it difficult to call out words in their mental lexicon.

In communication, people with Broca's aphasia will have difficulty organizing thoughts, feelings, and 
desires into meaningful symbols that can be understood by others. Spoken speech is not fluent, paused/interrupted and other people often cannot understand him. Sentences of conversation are short and monotonous, as the informant did when showing time deixis with the intention of pointing to the mushala or mosque. He is able to understand and interpret the given stimulus, but he has difficulty to express it so that gestures are used.

The deixis phenomenon observed from the informants is that they often use spatial deixis and time deixis. Uniquely, informants find it difficult to express content words in the form of nouns when pointing at something so that the informants deal with this by using spatial deixis, which is clarified with gestures. Gestures for people with aphasia cannot be separated from deixis. On the other hand, deixis cannot be separated from gestures when informants make communication strategies.

When carrying out a communication strategy, the appointment of time deixis made by the informant was not arbitrary because the meanings indicated were all the same, namely related to terms in Islamic worship.

The same knowledge, situation context, and linguistic nature produce understanding from the speech partner to interpret the meaning of the information spoken by the informant. Although sometimes the meaning of the speech is difficult to interpret.

\section{REFERENCES}

[1] M. L. Sekine, K \& Rose, "The relationship of aphasia type and gesture production in people with aphasia," Am J Speech Lang Pathol ., vol. 22(4), pp. 662-672, 2013, doi: 10.1044/1058-0360(2013/120030 .

[2] C. Kong, A. P. H., Law, S. P., Wat, W. K. C., \& Lai, "Co-verbal gestures among speakers with aphasia: Influence of aphasia severity, linguistic and semantic skills, and hemiplegia on gesture employment in oral discourse," J. Commun. Disord., vol. 56, pp. 88102, 2015, doi: https://doi.org/10.1016/j.jcomdis.2015.06.007.

[3] J. L. Fontanari, "Pragmatic elements of the speech of Broca's aphasic patients: clinical preliminar study," Arq. Neuro-Psiquiatr., vol. 45 (1) • M, 1987, doi: https://doi.org/10.1590/S0004282X1987000100003.
[4] R. Varley, "Deictic Terms, Lexical Retrieval and Utterance Length in Aphasia: An Investigation of Inter-Relations," J. Disord. Commun., vol. 28, pp. 23-41, 1993.

[5] G. Daumüller, M., \& Goldenberg, "Therapy to improve gestural expression in aphasia: A controlled clinical trial.," Clin. Rehabil., vol. 24, pp. 55-65, 2010, doi: 10.1177/0269215509343327.

[6] C. de Ruiter, J. P., \& de Beer, “A critical evaluation of models of gesture and speech production for understanding gesture in aphasia," Aphasiology, vol. 27, pp. 1015-1030, 2013, doi: 10.1080/02687038.2013.797067.

[7] A. all. Nispen, K., "Part of the message comes in gesture: how people with aphasia convey information in different gesture types as compared with information in their speech," Aphasiology, vol. 31:9, pp. 1078-1103, 2017, doi: 10.1080/02687038.2017.1301368.

[8] L. Cummings, Clinical Pragmatics. Cambridge University Press, 2009.

[9] J. Lyons, "Deixis, space and time. In Semantics," in Semantics, Cambridge University Press, 1977, pp. 636-724.

[10]M. Fludernik, "Shifters and deixis: Some reflections on Jakobson, Jespersen, and reference," pp. 193230, 2009, doi: https://doi.org/10.1515/semi.1991.86.3-4.193.

[11]B. K. Purwo, DeiksisDalam Bahasa Indonesia. Jakarta: Balai Pustaka, 1984.

[12]S. Levinson, Pragmatics. Cambridge: Cambridge University Press, 1983.

[13]L. Cummings, Pragmatics, A Multidisciplinary Perspektive. New York: Oxford University Press, 1999.

[14]A. H. Pearl, L.P \& Emsellem, "The Central Nervous System : Brain and Cord," Neurol. a Prim. localization, p. p 3-27, 2014.

[15]J. Batson, DW. \& Avent, "Adult Neurogenic Communication Disorders," Phys. Med. Rehabil., pp. 54-57, 2011.

[16]J. Tan, Practical Manual of Physical Medicine and Rehabilitation. St. Louis (Missouri): Mosby, 1998.

[17]L. Kusumoputro, S dan Sidiarto, Afasia: Gangguan Berkomunikasi Pascastroke Otak. Jakarta: Universitas Indonesia, 2009.

[18]T. Pedersen, PM., Vinter, K., Olsen, “Aphasia after 
stroke: type, severity and prognostic. The

Copenhagen Aphasia Study," Cerebrovasc Dis, vol.

1, no. 17, pp. 36-43, 2004.

[19]J. Guyton, AC \& Hall, Textbook of Medical

Physiology. Philadelphia: Elsevier Saunders, 2006.

[20]J. W. Creswell, Research Design: Pendekatan Metode Kualitatid, Kuantitatif, dan Campuran, 4th ed. Yogyakarta: Pustaka Pelajar, 2019.

[21]T. Djajasudarma, Semantik 2: Relasi Makna Paradigmatik, Sintagmatik, dan Derivasional. Bandung: Refika Aditama, 2016.

[22]N. Greschwind, "Specializations of the Human Brain in Human Communication: Language and Psycobiological Bases, Reading from Scientific America," W. S.-Y. Wang, Ed. San Fransisco: W.H. Freeman and Company, 1981.

[23]G. Yule, Pragmatik. Yogyakarta: Pustaka Pelajar, 1996. 